\title{
SISTEM KEAMANAN SEPEDA MOTOR BERBASIS MIKROKONTROLER DAN MODUL GSM
}

\author{
Deri Andesta, Rian Ferdian \\ Jurusan Sistem Komputer, Universitas Andalas, Padang, 25163
}

\section{ARTICLE INFORMATION}

Received: February 00, 00

Revised: March 00, 00

Available online: April 00, 00

\section{KEYWORDS}

Security, GSM Module, SW420 Vibration

Sensor, Voltage Sensor, Android

\section{CORRESPONDENCE}

E-mail: rian.ferdian@ @ti.unand.ac.id

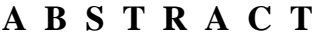

\begin{abstract}
This study aims to create a security system that can work when motorcycles are parked or are being driven. Most congenital motorcycle security systems work only when the motor is parked, such as the security of the ignition key and the handlebar lock. In fact, not infrequently theft is done by robbing a motorcycle that is being driven by owner. Then made a system using Arduino microcontroller platform, GSM SIM800L module and mobile device. The system created consists of three MODE, the MODE PARKIR, MODE JALAN and MODE MANUAL that can be selected through mobile devices with Bluetooth connection. In MODE PARKIR there are two sensors that detect the theft action, the vibration sensor SW420 and Voltage sensor. If the ignition key is successfully broken or there is a motorcycle on the motorcycle GSM SIM800L module will give notification in the form of SMS and phone call. For Roadside mode the motorcycle ignition system will be activated automatically and the owner can directly use the vehicle without having to manually activate the ignition. When the motorcycle is seized the owner can turn off the vehicle engine by pressing the Stop button on the mobile device and GSM module SIM800L will send the coordinates of the nearest BTS.
\end{abstract}

\section{PENDAHULUAN}

\section{A. Latar Belakang}

Sepeda motor menjadi sarana transportasi yang umum digunakan oleh banyak orang karena harganya terjangkau dan efesien digunakan untuk aktifitas sehari-hari. Badan Pusat Satatistik (BPS) Indonesia mencatat peningkatan jumlah kendaraan bermotor dari 2013 sampai 2016, kenaikan terus terjadi dari tahun-tahun sebelumnya dari 84.732.652 unit menjadi 105.150.082 unit.[1] Dengan banyaknya jumlah kendaraan yang ada dan kebutuhan hidup yang mendesak menyebabkan kenaikan jumlah kasus kriminalitas diberbagai kota di Indonesia. Kota padang tidak luput dari hal ini, terbukti sepanjang tahun 2017 BPS Sumbar mencatat terjadi 2.709 kasus pencurian kendaraan bermotor dan kasus ini meningkat dari tahun sebelumnya.[2]

Dengan banyaknya pencurian sepeda motor yang terjadi membuktikan bahwa lemahnya keamanan yang terdapat pada kendaraan tersebut. Sebagian besar pabrikan hanya menyediakan pengamanan dasar seperti: kunci stang dan inovasi dari kunci kontak saja. Namun sistem kerja dari pengamanan seperti ini belum dapat diandalkan oleh pemilik sepeda motor. Sebab para pelaku pencurian kendaraan bermotor memiliki pengalaman dan modus yang bermacam-macam. Beberapa modus yang sering digunakan oleh para pencuri motor adalah menggunakan kunci T untuk membobol kunci kontak sepeda motor.

Selanjutnya menggunakan cairan setan (bahan kimia) sehingga kunci kontak yang terkena cairan akan meleleh dan dengan mudah pelaku menyalakan motor serta membawa kabur tanpa menimbulkan kecurigaan. [3] Sebelumnya telah ada penelitian tentang sistem keamanan sepeda motor menggunakan sidik jari[4]. sistem ini menggunakan modul fingerprint dan keypad, yang merespond dengan menggunakan saklar untuk menghidupkan dan mematikan kendaraan bermotor. Kelemahan dari sistem ini berupa inputan sidik jari yang terbatasi dan modul yang digunakan relatif mahal.

Penelitian lain yang membahas tentang keamanan sepeda motor adalah dengan pemanfaatan NFC sebagai pengganti kunci mekanik[5] dan merancang kunci kombinasi menggunakan mikrokontroler[7]. Dari sistem yang sudah ada masih terdapat kelemahan, dimana keamanan yang ditawarkan hanya berlaku ketika sepeda motor diparkirkan(diam). Sedangkan modus yang tak jarang digunakan oleh para pencuri sepeda motor yaitu merampas motor dijalanan sepi (begal) dan membawa kabur sepeda motor hasil curiannya tersebut. 
Mengingat modus dari pencurian sepeda motor yang beragam dibutuhkan sistem yang dapat bekerja saat motor diparkirkan dan juga saat dikendaraai oleh pemiliknya, hal ini untuk menimalisir pencurian motor dengan cara perampasan(begal). Untuk mewujudkan sistem tersebut penulis menggunakan sensor Tegangan dan SW420 sebagai pendeteksi aksi pencurian pada area parkir dan memberi notifikasi ke pemilik melalui modul GSM. Untuk mengendalikan pengapian penulis menggunakan relay 4 channel yang akan diperintah oleh mikrokontroler sesuai intruksi dari smartphone pemilik via bluetooth. Jadi sesaat setelah terjadi perampasan mesin sepeda motor akan mati secara otomatis dan tidak dapat dihidupkan.Maka dari itu penulis membuat sebuah rancangan penelitian yang berjudul "Sistem Keamanan Sepeda Motor Berbasis Mikrokontroler Dan Modul GSM" Dengan rancangan ini diharapkan dapat memberikan keamanan lebih pada kendaraan bermotor, baik saat diparkirkan maupun sedang dikendaraai oleh pemiliknya dan diusulkan agar dapat mengurangi kasus kejahatan khususnya pencurian sepeda motor (curanmor) di Sumatera Barat.

\section{B. Tujuan}

Adapun tujuan yang ingin dicapai dalam penelitian ini antara lain adalah :

1. Sistem mampu mengidentifikasi terjadinya pencurian dengan sensor getar SW420 dan sensor Tegangan.

2. Sistem mampu mengirim notifikasi dan mendapatkan lokasi jaringan dengan modul GSM SIM800 jika terjadi pencurian.

3. Sistem mampu beroperasi saat sepeda motor dirampas (begal) dan mematikan sistem pengapian motor secara otomatis serta memberikan notifikasi ke lingkungan.

\section{Manfaat}

Manfaat dari penelitian ini adalah:

1. Meningkatkan keamanan sepeda motor sewaktu parkir dengan memanfaatkan sensor sebagai pendeteksi aksi pencurian dan mengirim notifikasi kepada pemilik

2. Meningkatkan keamanan saat berkendara mengingat kasus pencurian tak jarang dilakukan dengan aksi nekat para pelaku seperti merampas kendaraan dijalanan sepi (begal).

3. Menambah fungsi smartphone yaitu sebagai alat untuk mengamankan dan mengendalikan pengapian sepeda motor.

\section{LANDASAN TEORI}

\section{A. Keamanan Sepeda Motor}

Fitur pengaman bawaan dari pabrikan sepeda motor antara lain:

\section{Garpu Pengunci}

Pengamanan dengan garpu pengunci dapat ditemui pada motor Honda Supra Fit, Suzuki Shogun 125 atau motor lainnya yang lahir ditahun 2000-an. Garpu pengunci terletak pada di kiri atau kanan suspense depan motor.[16]

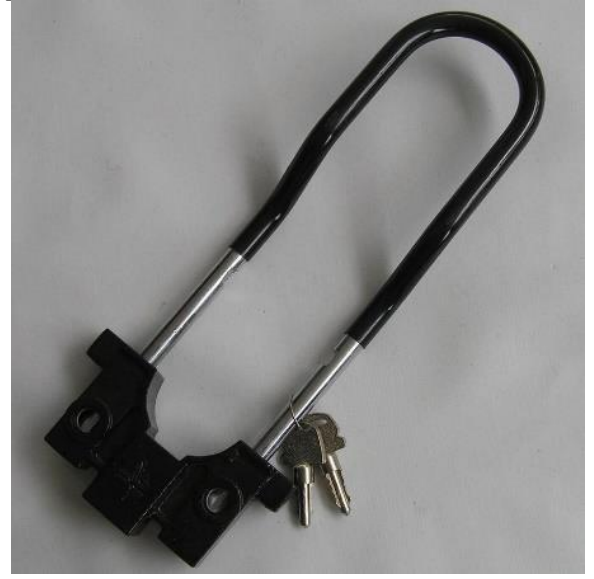

Gambar 2.1 Garpu Pengunci [17]

\section{Magnetic Key}

Pabrikan motor berinovasi dengan menyematkan kunci magnet, yang sepaket dengan rumah kunci yang ada penutupnya, atau biasa disebut secure shutter key. Untuk membuka penutup kunci tersebut, dapat dibuka dengan magnet pada pangkal kunci. Setiap unit motor memiliki desain magnet yang berbeda untuk kunci dan rumah kuncinya.

sehingga kunci motor magnetic lain tidak dapat dibuka rumah kunci motor yang sama. Namun tetap saja, seribu akal maling masih bisa membobol kunci tersebut dengan memasukkan dengan kunci $\mathrm{T}$ atau menyiramkannya dengan cairan setan agar penutup dan rumah kunci rusak.[16][17]

Berikut merupakan gambar dari magnetic key:

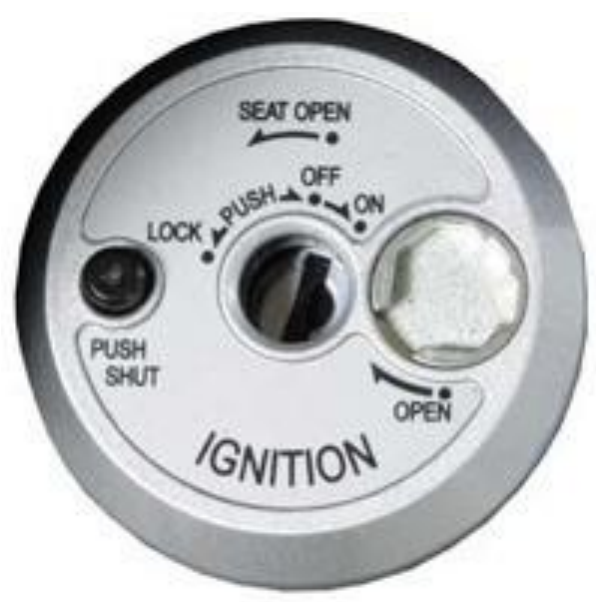

Gambar 2.2 Kunci Magnetic[17]

\section{Kunci Immobilizer}

Fitur keamanan yang lebih futuristic adalah penggunaan kunci immobilizer. Produk dari vespa dan Yamaha XMax saja yang sudah menyematkan immobilzer pada setiap unitnya. Sama dengan kunci immobilizer pada mobil, perangkat keamanan ini terbukti ampuh karena sistemnya menggunakan gelombang transmitter seperti RF-IDE.

Rumah kunci immobilzer akan dibenamkan Immobilizer Control Unit (ICU), yang tersambung dengan Engine 
Control Unit(ECU), dan kunci serta remotnya juga disematkan chip transponder yang nantinya akan menangkap gelombang yang dikirim oleh anak kunci tersebut.[16]

Cara kerjanya, saat anak kunci dimasukkan ke dalam rumah kunci dan diputar pada posisi ON, komponen IC akan mengirimkan sinyal menuju trasponder pada anak kunci, kemudian trasponder pada anak kunci akan mengirimkan sinyal balik pada ICU. Apabila kode sinyal sama atau sesuai dengan data di ECU, maka mesin dapat dinyalakan.

Berikut merupakan cara kerja kunci immobilizer:

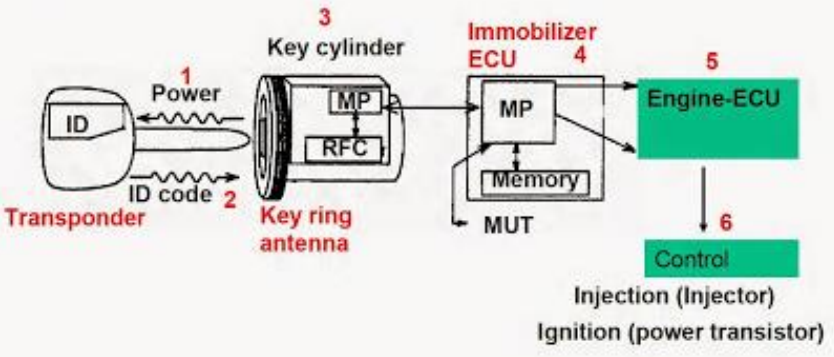

Gambar 2.3 Cara Kerja Kunci Immobilizer[16]

Sama halnya dengan teknologi keyless pada Yamaha Aerox 155R-Version dan Yamaha XMax , saat remot kunci mendekati motor, ICU pada motor akan mengirimkan sinyal pada remot kunci dan chip pada remot akan mengirim kode sinyal balik kepada ICU sehingga motor dapat dihidupkan.[18]

Berikut merupakan gambar teknologi keyless Yamaha Airox 155R:

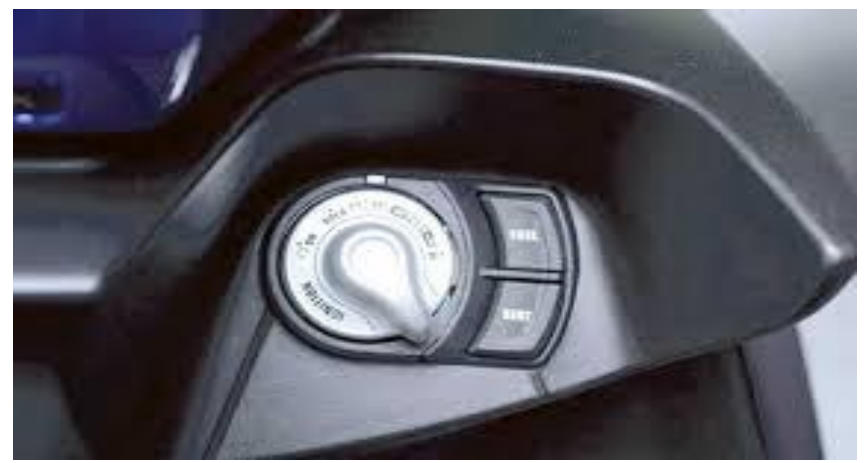

Gambar 2.4 Teknologi Keyless Yamaha Airox 155R[16]

\section{Remote Alarm}

Selain magnetic key dan immobilizer, sepeda motor pun juga dapat ditambahkan alarm. Fungsi remot alarm antara lain dapat mengaktifkan immobilizer, sehingga apabila kunci kontak dibobol maka motor akan mengeluarkan bunyi, selain itu remot juga dapat memberi tau posisi motor dengan cara menyalakan lampu sein sepeda motor melalui remot (answer back control). Fitur remot ini dapat ditemui pada unit YamahaGT 125 Eagle Eye Spesial Edition.[16][19]

Berikut merupakan gambar Yamaha GT 125 Eagle Eye Spesial Edition:

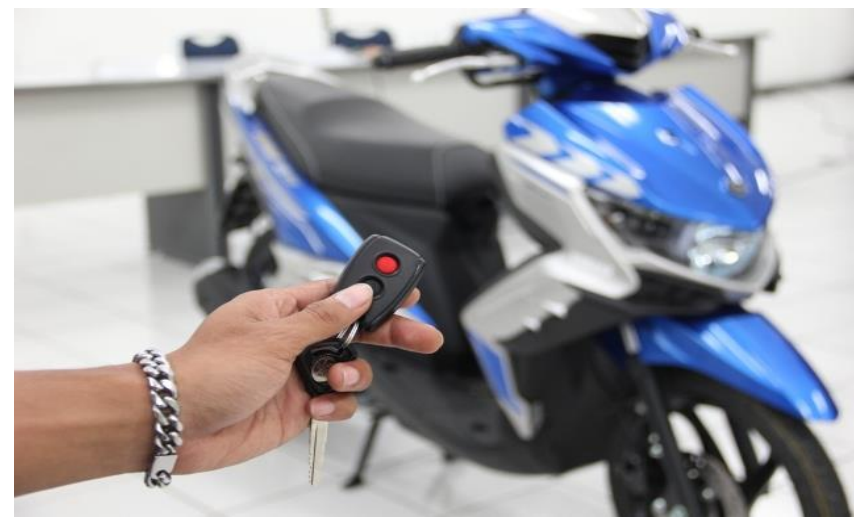

Gambar 2.5 Remot Yamaha GT 125R[19]

\section{B. Modus Operandi Pencurian Sepeda Motor}

1. Alat Alat Yang Digunakan

a.Gunting khusus Besi

Modus yang digunakan adalah dengan memotong gembok dengan gunting besi atau gunting yang dirancang khusus untuk memotong besi. Alat ini digunakan pelaku apabila keadaan motor berada di dalam halaman rumah yang memiliki pagar damn diamankan dengan gembok atau gembok yang memang dipasang pada motor agar aman. Dengan alat ini mempermudah pelaku dalam mendapatkan target walaupun sudah di gembok.[20]

\section{b.Menggunakan Kunci T}

Kunci $\mathrm{T}$ adalah alat yang paling sering digunakan pelaku pencurian sepeda motor karena lebih mudah dalam penggunaan dan mempercepat proses pada saat pelaku melaksanakan aksi kejahaatan pencurian sepeda motor. Pelaku-pelaku curanmor mendapatkan kunci bukan dari sebuah took penjual kunci tetapi membuat sendiri kunci $\mathrm{T}$ yang terbuat dari kunci L dan kemudian dipipihkan serta dibentuk menjadi kunci $\mathrm{T}$ dengan bagian-bagiannya agar dapat masuk sesuai lubangkunci kontak motor.[20]

\section{c.Menggunakan Karcis Palsu}

Karcis palsu biasanya berupa selembar kertas kecil yang berisi seperti nama-nama instansi, nama took, atau nama tempat lainnya. Didalam karcis juga tertulis plat nomor motor dan tarif harga parkir motor.[20]

\section{d.Menggunakan Kunci Kontak Palsu}

Alat ini tidak akan merusak lubang kunci kontak sepeda motor, sebab kunci kontak palsu dibuat sesuai dengan ukuran kunci kontak asli dari motor-motor target pelaku kejahatan.[20]

\section{Mikrokontroller}

Mikrokontroler merupakan sebuah mikrokomputer yang berfungsi sebagai kendali dan otomatisasi mesin dan proses. Mikrokontroler adalah sebuah sistem komputer yang terintergrasi pada satu chip mikroprosesor, memiliki memori dan perangkat interface dengan jumlah tertentu.[9]

\section{Arduino Uno}

Arduino adalah papan rangkaian elektronik open source dan didalamnya terdapat komponen utama sebuah chip mikrokontrollel dengan jenis AVR dari perusahaan 
ATMEL. Sedangkan, Arduino UNO adalah sebuah board mikrokontroler yang didasarkan pada ATmega328.[6]

Berikut merupakan gambar dari board Arduino Uno:

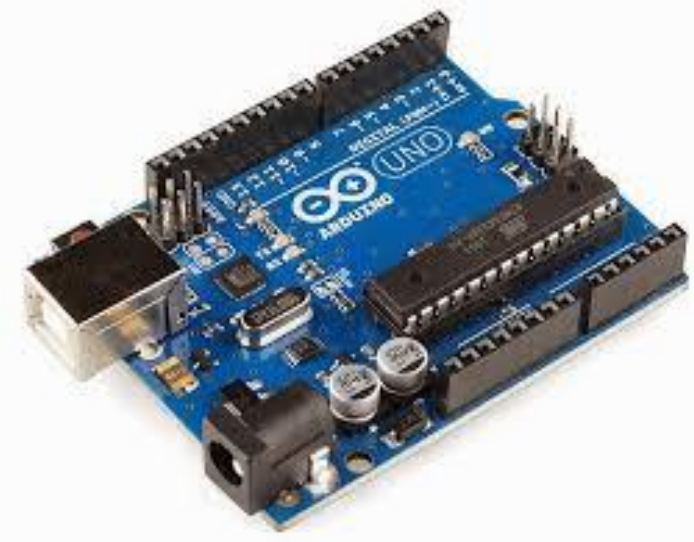

Gambar 2.6 Board Arduino Uno[6]

Berikut merupakan tabel Spesifikasi Arduino Uno:

Table 2.1 Spesifikasi Arduino Uno[6]

\begin{tabular}{|l|c|}
\hline \multicolumn{1}{|c|}{ Mikrokontroler } & ATmega328 \\
\hline Tegangan pengoperasian & $5 \mathrm{~V}$ \\
\hline $\begin{array}{l}\text { Tegangan input yang } \\
\text { disarankan }\end{array}$ & $7-12 \mathrm{~V}$ \\
\hline Batas tegangan input & $6-20 \mathrm{~V}$ \\
\hline Jumlah pin I/O digital & $\begin{array}{c}\text { 14 (6 di antaranya } \\
\text { menediakan keluaran } \\
\text { PWM) }\end{array}$ \\
\hline Jumlah pin input analog & 6 \\
\hline Arus DC tiap pin I/O & 40 mA \\
\hline Arus DC untuk pin 3.3V & $\begin{array}{c}\text { 32 KB (ATmega328), yang } \\
\text { mana sekitar 0.5 KB } \\
\text { digunakan oleh bootloader. }\end{array}$ \\
\hline Memori Flash & $2 \mathrm{~KB}$ (ATmega328) \\
\hline SRAM & $1 \mathrm{~KB}$ (ATmega328) \\
\hline EEPROM & 16 Hz \\
\hline Clock Speed & \\
\hline
\end{tabular}

\section{E. Catu Daya}

Arduino dapat diberikan daya melalui koneksi USB atau power supply eksternal. Power supply bisa berasal dari adaptor AC-DC atau baterai. Arduino dapat beroperasi dengan menggunakan tegangan sebesar 6-20 V.

Jika tegangan yang diberikan kurang dari $7 \mathrm{~V}$, Pin output 5 $\mathrm{V}$ arduino akan menyuplai tegangan kurang dari $5 \mathrm{~V}$ dan membuat board menjadi tidak stabil.Dan jika menggunakan tegangan yang melebihi $12 \mathrm{~V}$, regulator tegangan akan cepat panas dan menyebabkan kerusakan pada board. Pemberian tegangan yang direkomendasi adalah sebesar 7-12 V.[6]

\section{F. Modul SIM800L}

Modul SIM800L merupakan salah satu jenis modul GSM/GPRS serial yang paling popular digunakan oleh para penghobi, maupun professional elektronika untuk berbagai keperluan pengendalian jarak jauh. Untuk saat ini terdapat beberapa tipe dari Breakout Board, tetapi yang

54 Deri Andesta paling banyak dijual di Indonesia yaitu versi mini dengan kartu GSM jenis Micro SIM.[11]

Berikut merupakan gambar modul GSM SIM800L :

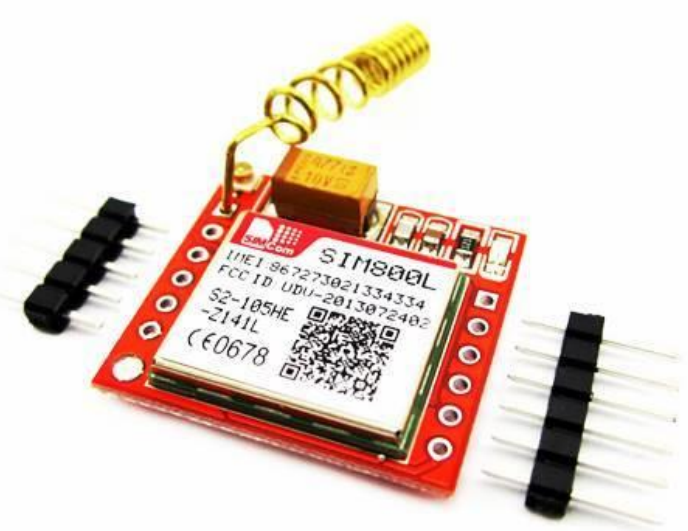

Gambar 2.9 Modul GSM SIM 800L [11]

Modul GSM ini menggunakan ic chip : SIM800. Tegangan ke Vcc: antara 3.7 - 4.2 Vdc dan disarankan menggunakan 3.7 Vdc agar tidak terdapat notifikasi "over voltage". Bekerja pada frekuensi jaringan GSM yaitu QuadBand (850 / 900 / 1800 / 1900Mhz). Suhu pengoperasian normal : $40 \mathrm{oC} \sim+85 \mathrm{oC}$.

Menggunakan port TTL seria; port, sehingga dapat langsung diakses menggunakan mikrokontroler tanpa perlu memerlukan MAX232. Terdapat Led pada modul yang berfungsi sebagai indicator, apabila ada sinyal GSM maka akan berkedip perlahan, tetapi apabila tidak ada sinyal maka akan berkedip cepat. [11]

Pada setiap jaringan GSM yang terkoneksi dengan menara BTS akan menyimpan berbagai informasi, salah satunya informasi tentang kode atau posisi dari BTS yang sedang terhubung dengan GSM tersebut. Selain info tersebut meliputi MCC, MNC, LAC, CID dll. Setiap negara memiliki MCC yang berbeda, untuk negara indonesia kode MCC-nya adalah 510, malaysia MCC $=502$, Italy MCC $=222$ dll. Untuk lebih jelas berikut merupakan tabel kode MCC dan MNC negara Indonesia dan Portugal.

\section{G. Short Massage Service (SMS)}

SMS merupakan fasilitas standart dari global system for mobile communication (GSM). SMS dapat dikirimkan melalui telepon hanya dalam beberapa detik selama berada pada jangkauan pelayanan GSM. Prinsip kerjanya adalah menyimpan dan menyampaikan pesan (store and forward). Pesan tidak langsung dikirim melainkan didimpan terlebih dahulu di SMS-Center (SMSC).

SMS center adalah program yang memiliki program yang memiliki fungsi utama untuk mengatur distribusi data dan informasi dalam format dan aturan penulisan tertentu agar bisa memberikan output dan keluar informatif yang beragam sesuai dengan kategorinya. 
SMS gateway adalah sebuah sistem aplikasi yang digunakan untuk mengirim juga menerima SMS, dan biasanya digunakan pada aplikasi bisnis, baik untuk kepentingan broadcast promosi, servis informasi terhadap pengguna, penyebaran content produk dan lain-lain. Namun pada penelitian ini penulis menggunakan layanan SMS sebagai media untuk mengirim/menerima perintah ke modul GSM SIM800.[21]

\section{H. Sensor Tegangan}

Sistem keamanan sepeda motor ini penulis menggunakan sensor Tegangan. Sensor Tegangan difungsikan sebagai pendeteksi apakah kunci kontak motor ON atau OFF, hal ini digunakan sebagai acuan apakah sepeda motor dalam keadaan aman atau dibobol oleh pencuri. Dalam penelitian ini penulis menggunakan sensor tegangan DC 5V. Modul ini bekerja berdasarkan prinsip resistive divider, membuat tegangan yang akan dideteksi berkurang 5x lipat.

Tegangan input analog pada Arduino 0-5v, sehingga tegangan maximum yang dapat dideteksi oleh sensor adalah $5 \mathrm{x} 5 \mathrm{v}=25 \mathrm{v}$. Jika menggunakan sistem tegangan $3.3 \mathrm{v}$, maka tegangan maximum yang dapat dideteksi adalah sebesar $5 \mathrm{x} 3.3 \mathrm{v}=16.5 \mathrm{v}$. AVR Chip pada Arduino memiliki AD 10-bit, jadi modul ini memiliki ketelitian $0.00489 \mathrm{v}(5 \mathrm{v} / 13)$. Sehingga nilai tegangan minimum yang dapat dideteksi adalah $5 \mathrm{x} 0.00489 \mathrm{v}=0.445 \mathrm{v}$ (bukan 0v)[21]

Berikut merupakan gambar dari sensor Tegangan :

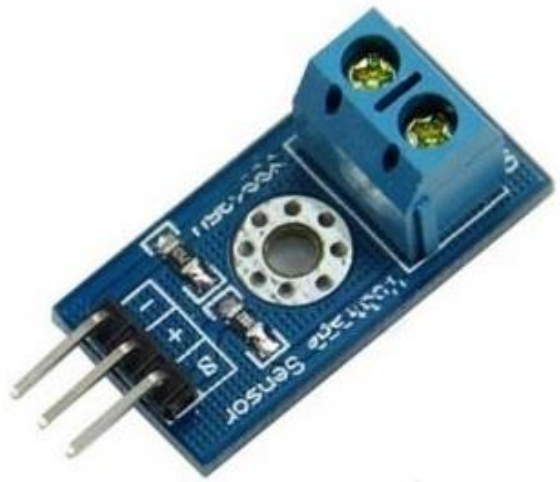

Gambar 2.10 Sensor Tegangan [21]

\section{Sensor Getaran SW420}

Pada penelitian ini sensor getar yang digunakan bertipe SW- 420 yang digunakan untuk mendeteksi adanya getaran dalam kondisi tertentu pada sepeda motor. Getaran yang dimaksud apabila sesorang pencuri hendak membobol sepeda motor maka sensor akan mendeteksi getaran yang ditimbulkan oleh pencuri. Sensor akan dipasang pada area body motor tepatnya didekat kunci kontak.[27] Berikut merupakan gambar dari sensor getaran SW- 420:

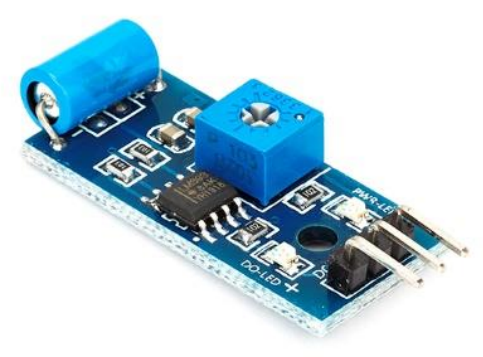

Gambar 2.11 Sensor Getaran SW- 420 [27]

Spesifikasi Sensor SW420 sebagai berikut:

1.Tegangan kerja $3.3-5 \mathrm{~V}$

2.Format output 0 dan 1 (LOW, HIGH)

3.Menggunakan komparator LM393

4.Mampu menghantar lebih dari $15 \mathrm{~mA}$

5.Bersifat Normally Close

6.Papan PCB berukuran $3.2 \mathrm{~cm} \times 1.4 \mathrm{~cm}$

7.Lampu indikator menyala jika tidak ada getaran

8.Dan lampu indikator mati jika terdeteksi getaran

\section{J. Relay 4Channel}

Relay adalah saklar (switch) yang dioperasikan secara listrik dan merupakan komponen Elektromekanikal yang terdiri dari 2 bagian utama yakni Elektromagnet (coil) dan mekanikal (seperangkat kontak saklar/switch). Relay menggunakan prinsip elektromagnetik untuk menggerakkan kontak saklar sehingga dengan arus listrik yang kecil (low power) dapat menghantarkan listrik yang bertegangan lebih tinggi[8] Relay bekerja berdasarkan elektromagnetik untuk menggerakkan sejumlah kontraktor yang tersusun atau sebuah saklar elekronis yang dapat dikendalikan dari rangkaian elekronik lainnya. Berbeda dengan saklar, penggerak kontraktor (on atau off) dilakukan manual tanpa perlu arus listrik.[12]

Berikut merupakan gambar modul relay 4 channel:

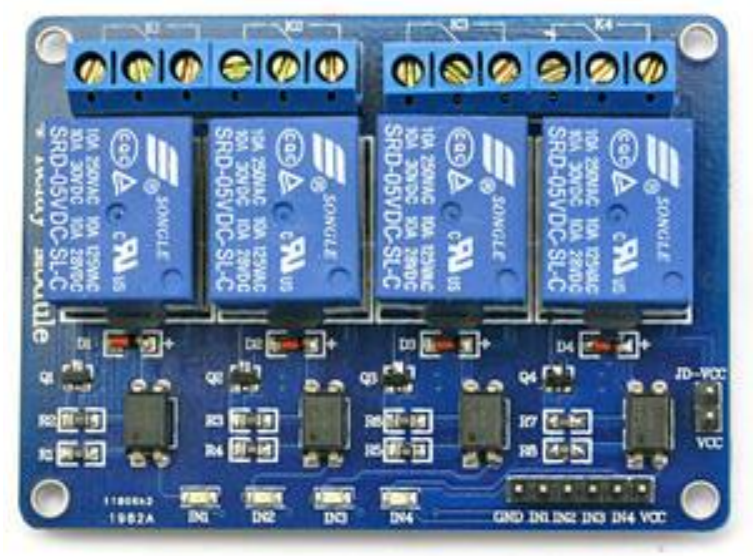

Gambar 2.12 Modul Relay 4 channel [12]

Sebagai komponen elektronika, relay mempunyai peran penting dalam sebuah system rangkaian elektronika dan rangkaian listrik untuk menggerakkan sebuah perangkat yang memerlukan arus besar tanpa terhubung langsung 
dengan perangkat pengendali yang mempunyai arus kecil. Dengan demikian relay dapat berfungsi sebagai pengaman.

\section{K. Modul Bluetooth HC05}

Bluetooth adalah protocol komunikasi wireless yang bekerja pada frekuensi radio $2.4 \mathrm{GHz}$ untuk pertukaran data pada perangkat bergerak seperti PDA, laptop, HP, dan lain-lain. Ada dua jenis Bluetooth serial dengan kode nomor ganjil dan genap. Bluetooth serial bernomor ganjil seperti HC-05 atau HC-03 adalah versi perbaikan dari Bluetooth serial yang bernomor genap HC-06 atau HC-04.

Perbedaan mendasar kedua jenis Bluetooth tersebut terletak pada AT command yang mereka miliki. Modul Bluetooth to serial bernomor ganjil dapat diatur sebagai Master dan slave, sedangkan modul Bluetooth dengan nomor genap tidak. Modul Bluetooth HC-05 terdiri dari 6 pin konektor, yang setiap pin konektor memiliki fungsi yang berbeda-beda.[13][14]

Deskripsi modul Bluetooth yang digunakan:

1.Low supply voltage $3.3 \mathrm{~V}$

2.Modul memilki 2 mode kerja (pemilihan mode kerja Bluetooth dapat dengan mengubah status pin 34-KEY). Status ini dirubah menggunakan AT command.

3.Boudrate, dapat diatur sesuai dengan kebutuhan user. Boudrate default adalah 9600.

4.Arus yang dibutuhkan pada saat proses pairing adalah $20 \mathrm{~mA}$ - $30 \mathrm{~mA}$. Sedangkan untuk berkomunikasi membutuhkan : 8mA.

Berikut merupakan gambar dari modul Bluetooth HC-05:

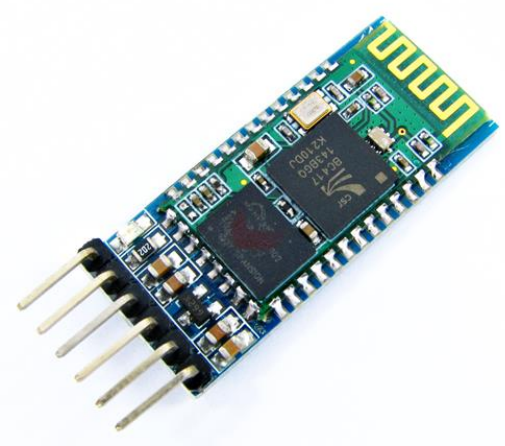

Gambar 2.6 Modul Bluetooth HC-05 [13]

\section{Push Button}

Sesuai dengan nama fungsinya saklar push button digunakan untuk memutuskan dan menghubungkan aliran listrik dengan cara ditekan bagian tombolnya. Pada bagian atasnya terdapat knop yang berfungsi sebagai area penekan , lalu disamping kiri dan kanan terdapat terminal, kontak normally open (NO) dan normally close (NC) berfungsi sebagai terminal wiring untuk dihubungkan dengan alat listrik lainnya, lalu mempunyai kapasitas beban sekitar 5 $\mathrm{A}[15]$.

Berikut merupakan gambar dari push button:

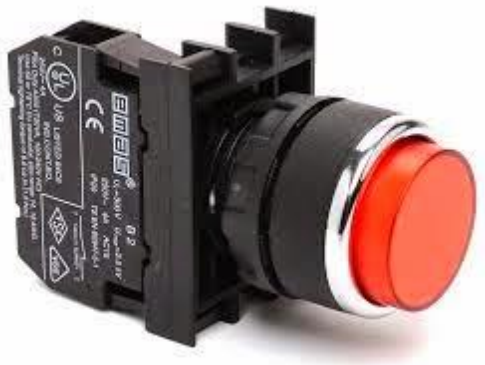

Gambar 2.14 Push Button [15]

\section{M.Buzzer}

Buzzer adalah sebuah komponen elektronika yang berfungsi untuk menghasilkan getaran suara. Pada dasarnya prinsip kerja buzzer hampir sama dengan loud speaker, jadi buzzer juga terdiri dari kumparan yang terpasang pada diafragma dan kemudian kumparan tersebut dialiri arus sehingga menjadi electromagnet.

Berikut merupakan gambar dari buzzer:

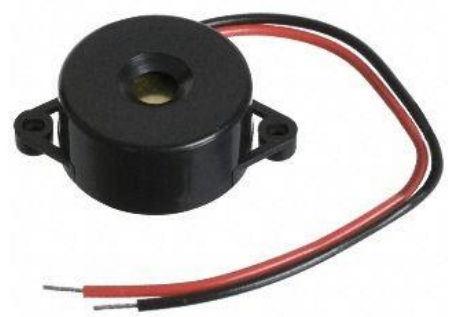

Gambar 2.15 Buzzer [15]

Pada sistem keamanan sepeda motor ini penulis merancangan aplikasi mobile menggunakan Android Studio versi 3.1. Aplikasi mobile merupakan aplikasi yang dapat digunakan walaupun pengguna berpindah dengan mudah dari satu tempat ke tempat lain. Saat ini sudah banyak sistem operasi yang mendukung aplikasi mobile seperti windows Phone Android. Android adalah sistem operasi untuk mobile device yang awalnya dikembangkan oleh Android Inc. Perusahaan ini kemudian dibeli oleh Google pada tahun 2005. Android dibuat berdasarkan kernel Linux yang dimodifikasi[26].

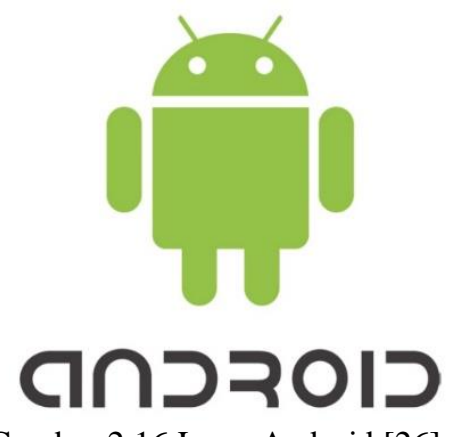

Gambar 2.16 Logo Android [26]

Android menyediakan platform terbuka bagi para pengembang untuk menciptakan aplikasi sendiri untuk digunakan oleh bermacam piranti bergerak. Android 
menyediakan android SDK yang dapat dengan mudah dipadukan dengan Integrated Development Environment (IDE).[26]

\section{METODE PENELITIAN}

\section{A. Jenis dan Metodologi Penelitian}

Jenis penelitian yang digunakan dalam pembuatan ini adalah penelitian eksperimental (Experimental Research). Penelitian eksperimental yaitu metode penelitian yang digunakan untuk melihat hubungan sebab dan akibat. Penelitian ini digunakan untuk mendapatkan hasil sesuai yang diinginkan serta dengan menghubungkan komponen dan alat-alat yang berbeda karakteristik.. Tahap-tahap yang akan dilakukan dalam penelitian ini ditunjukan pada Gambar 1.6

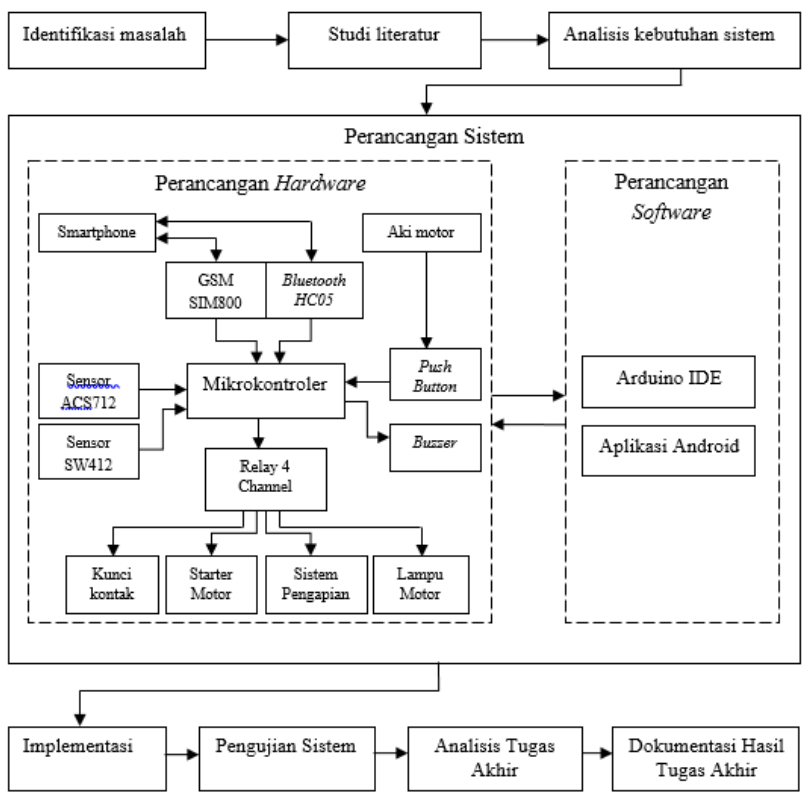

Gambar 3.1 Diagram Rancangan Penelitian

\section{B. Perancangan Proses}

Flowchart pada gambar (3.1) merupakan proses yang dilakukan sistem jika terjadi pencurian ketika motor diparkirkan. Pada tahap awal inisialisasi sensor dan perangkat yang digunakan. Selanjutnya sistem akan membaca data sensor dan melakukan pemilihan kondisi, jika kondisi terpenuhi maka sistem akan mengirim sms ke pemilik bahwa motor dalam keadaan bahaya. Untuk notifikasi pada motor maka buzzer dan lampu peringatan diaktif selama 5 menit.

Penjelasan dari gambar (3.2) flowchart jika motor dirampas(begal) adalah:

1. Inisialisasi Bluetooth,Gsm SIM800, Relay, BuzzerBluetooth,Gsm SIM800,Relay, Buzzer dalam kondisi normal.

2. Relay $1=\mathrm{ON}$ dan relay $2,3,4=\mathrm{OFFRelay} 1$ aktif karena berfungsi sebagai pengganti kunci kontak, relay $2,3,4$ tidak diperlukan saat motor digunakan.

3. Cek koneksi bluetooth pada proses ini sistem akan memeriksa koneksi bluetooth

4. Pemilihan kondisi Apakah koneksi bluetooth terputus atau tidak 
5. Pengapian normal jika kondisi tidak terpenuhi maka sistem akan mengatur relay dalam keadaan normal

6. Pengapian sepeda motor terputus Pada proses ini sistem akan memutuskan pengapian sepeda motor sebab koneksi bluetooth terputus. Hal ini berfungsi untuk mempersulit pelaku pencurian motor saat melakukan aksinya, karena motor akan mati dan tidak dapat dihidupkan walaupun dengan kick starter sekalipum.

7. Cek pesan masuk pada modul GSM Pada proses ini sistem akan membaca pesan yang diterima oleh modul GSM

8. Pemilihan kondisi Jika isi pesan sesuai dengan basis data yang ada pada sistem maka lanjut ke proses selanjunya. Dan jika tidak maka proses berakhir.

9. Jika kondisi terpenuhi maka sistem akan mengaktifkan fungsi modul GSM untuk meminta lokasi jaringan gsm yang tersedia dan didapatkan lokasi jaringan BTS dan kirim lokasi ke smartphone pemilik selanjutnya Pada proses trakhir sistem akan mencari lokasi jaringan gsm yang digunakan dan mengirimkan ke no pemilik yang sudah tersimpan.

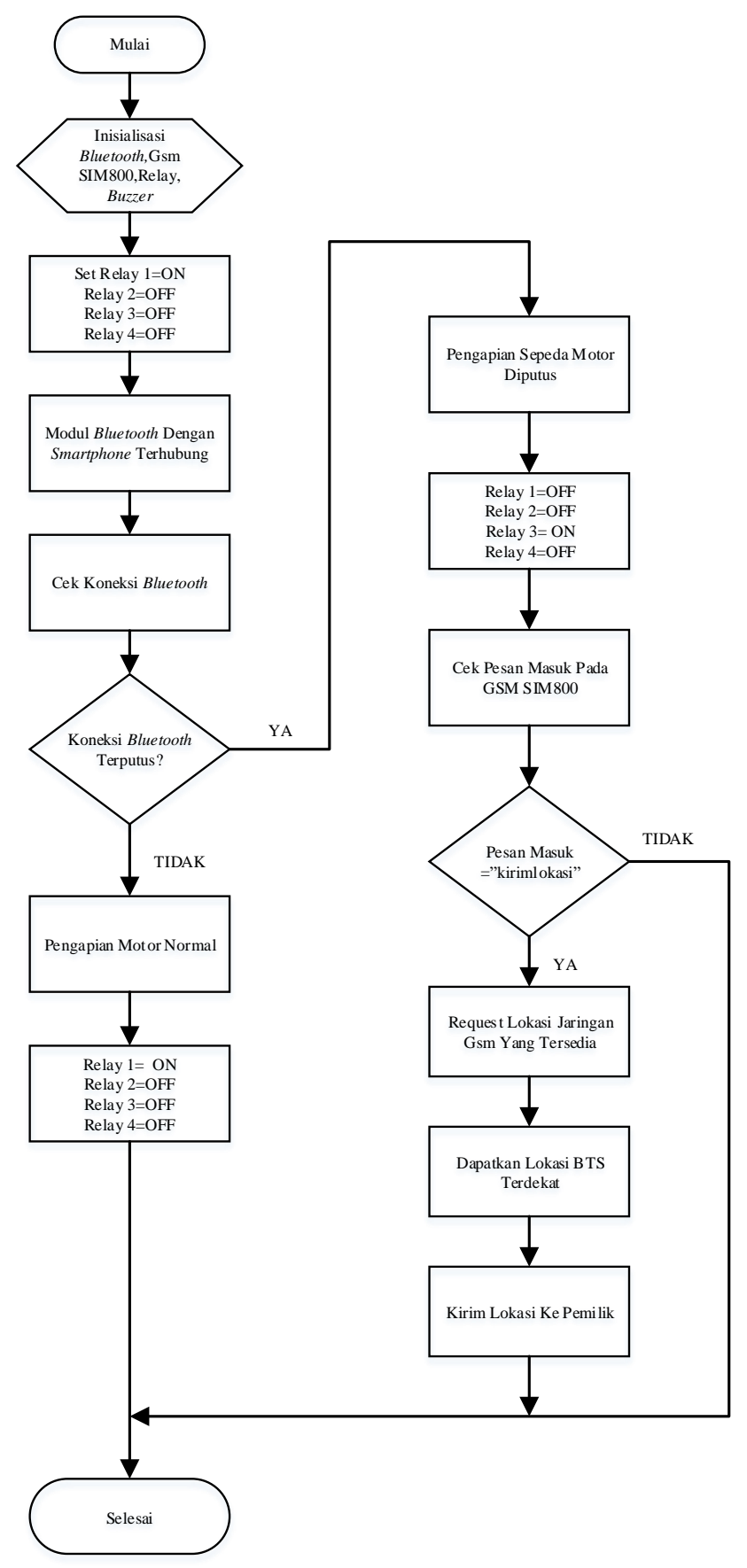

Gambar 3.2 Rancangan Proses Saat Mode Jalan

Berikut Merupakan Diagram Flowchart Aplikasi Mobile : 


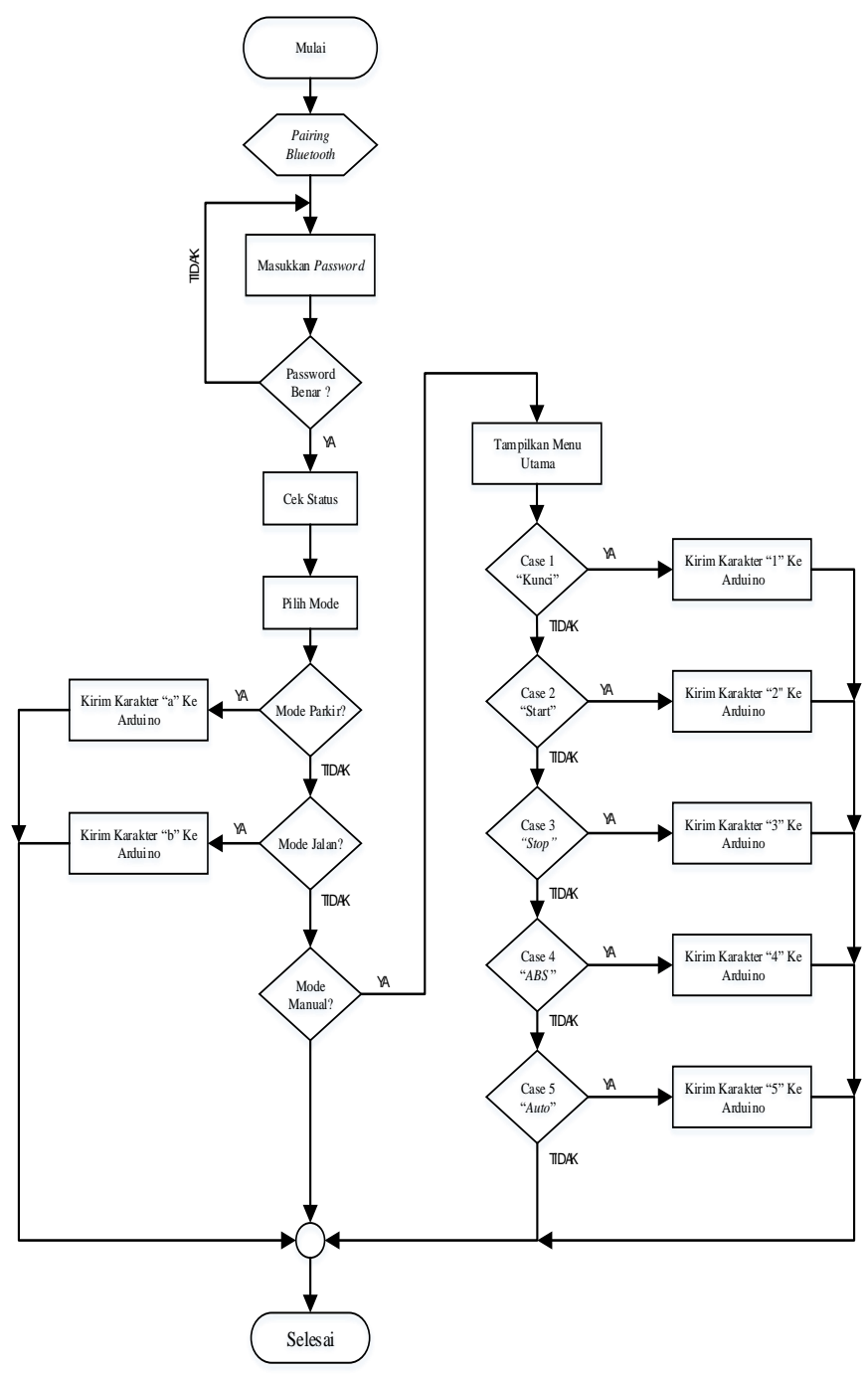

Gambar 3.3 Diagram Flowchart Aplikasi Mobile

Penjelasan diagram Gambar 3.3, pada langkah awal, User harus melakukan pairing bluetooth dan pastikan bluetooth terhubung dengan modul bluetooth $\mathrm{HC} 05$ yang ada pada sistem keamanan. Pilih mode parkir maka sensor akan aktif dan mendeteksi aksi pencurian sewaktu sepeda motor diperkirkan, Mode jalan untuk menggunakan sepeda motor dan Mode manual untuk mengontrol atau meremot pengapian motor, seperti hidup dan mematikan mesin sepeda motor.

\section{Perancangan Perangkat Keras}

Perangkat keras dari sistem ini terdiri dari Modul GSM SIM800L, Sensor Tegangan, Sensor Getaran SW420, Modul Bluetooth HC05, Buzzer, Smartphone. Berikut merupakan Gambar perancangan Perangkat Keras Sistem:

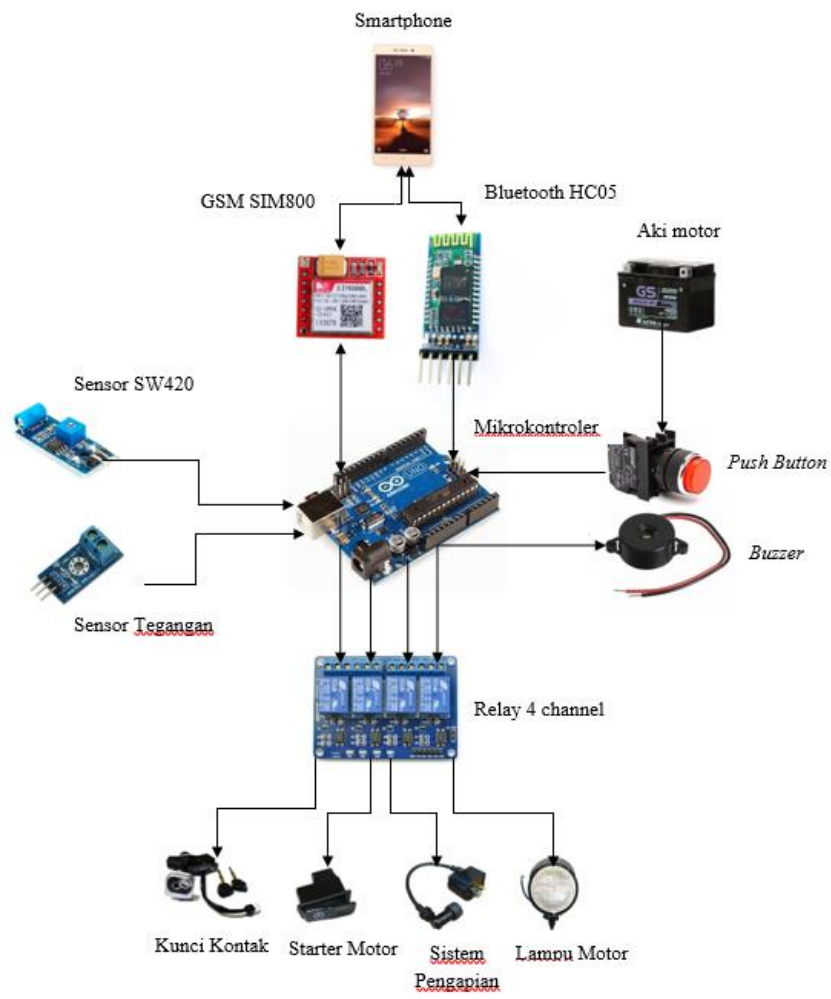

Gambar 3.4 Perancangan Perangkat Keras

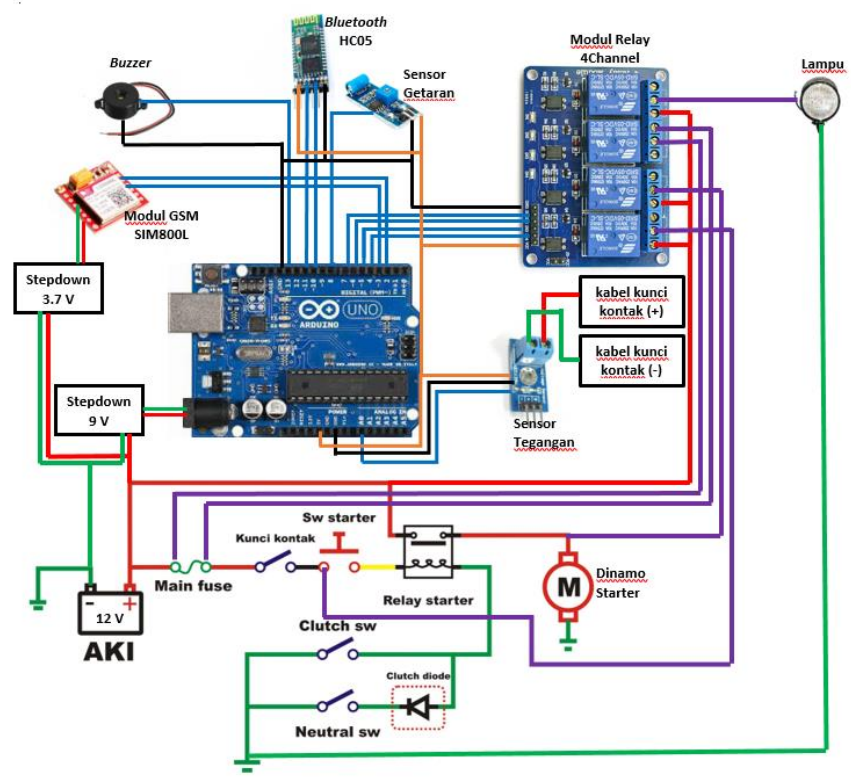

Gambar 3.5 Perancangan Skematik

Berdasarkan perancangan perangkat keras gambar (3.4) dan (3.5) prinsip kerja dari sistem ini adalah:

1.Sensor Tegangan digunakan sebagai pendeteksi Tegangan yang mengalir jika terjadi pembobolan kunci kontak pada sepeda motor.

2.Sensor SW420 pada sistem ini berfungsi untuk mendeteksi getaran

3.Modul GSM SIM800 digunakan untuk pengirim notifikasi berupa pesan kepada pemilik jika motor dalam keadaan bahaya, fungsi lain dari SIM800 adalah untuk memberikan lokasi jaringan sesuai koordinat BTS. 
4.Arduino UNO digunakan sebagai mikrokontroler yang menjadi pengontrol utama dari sistem, yang nantinya akan mengolah masukan yang telah dibaca oleh sensor, dan melakukan aksi sesuai program.

5.Modul Bluetooth HC05 digunakan sebagai media untuk komunikasi serial dari smartphone ke arduino uno.

6.Relay 4 Channel pada sistem ini digunakan untuk penyambung dan pemutus sistem pengapian motor, lampu, dan starter sepeda motor.

7.Smartphone pada sistem ini digunakan sebagai alat penerima notifikasi dari modul DSM SIM800 dan sebagai interface untuk mengendalikan pengapian sepeda motor melalui koneksi bluetooth.

8.Buzzer digunakan sebagai notifikasi terhadap pengendara.

9.Push button digunakan untuk penyambung tau memutuskan catu daya dari aki ke arduino uno.

10.Aki pada sistem ini berguna untuk sumber tegangan mikrokontroler.

\section{HASIL DAN ANALISA}

\section{A. Implementasi Perangkat Keras}

Sistem keamanan sepeda motor ini dibangun dengan menggunakan perangkat keras berupa sensor Tegangan, Sensor Geataran SW420, mikrokontroler Arduino UNO sebagai otak dari sistem ini dan selanjutnya Relay 4channel yang akan bertanggung jawab untuk menghidupkan dan mematikan pengapian sesuaai intruksi dari mikrokontroler, Bluetooth HC05 sebagai media komunikasi antara sistem dengan aplikasi mobile, GSM SIM800, Push Button dan Buzzer akan diletakkan pada sebuah kotak seperti terlihat pada Gambar 4.1 dan 4.2.

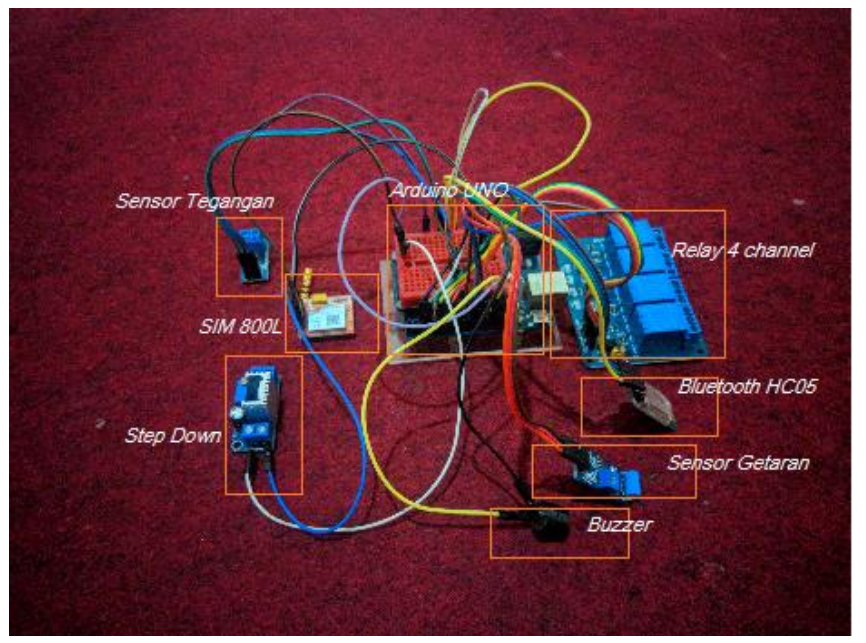

Gambar 4.1 Implementasi Perangkat Keras Tampak Luar

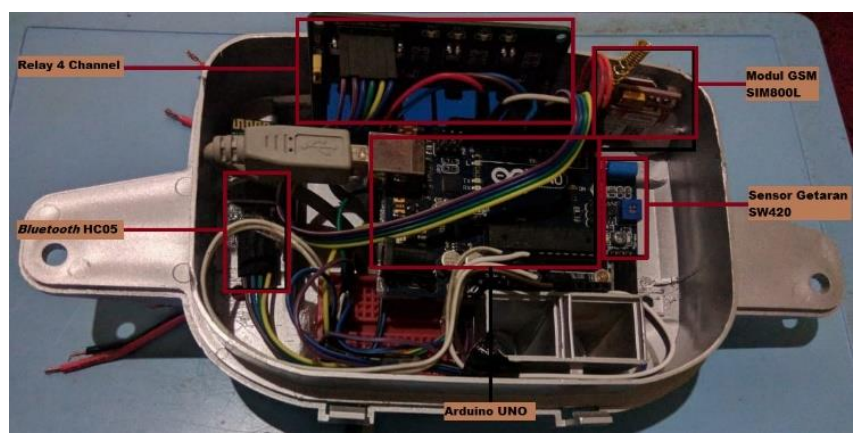

Gambar 4.2 Implementasi Perangkat Keras Tampak Dalam

Penjelasan masing-masing komponen:

1.Arduino UNO, berfungsi sebagai mikrokontroler yang memproses seluruh kerja dari sistem keamanan yang dirancang.

2.Modul GSM SIM800L, berfungsi sebagai pemberi notifikasi berupa SMS kepada pemilik saat sepeda motor dalam keadaan bahaya.

3.Sensor Getaran, berfungsi sebagai pendeteksi getaran yang diterima oleh sepeda motor.

4.Sensor Tegangan, berfungsi sebagai pendeteksi tegangan yang mengalir pada kabel kunci kontak saat kunci kontak dibobol.

5.Relay 4 Channel, berfungsi sebagai saklar pada sistem pengapian, kontak, dan lampu indikator.

6.Bluetooth HC05, berfungsi sebagai media komunikasi serial antara mikrokontroler dengan smartphone.

7.StepDown, berfungsi sebagai penurun tegangan yang masuk ke modul GSM SIM800L.

8.Buzzer, berfungsi untuk memberikan notifikasi jika sepeda motor dalam keadaan bahaya.

\section{B. Implementasi Perangkat Lunak}

Aplikasi mobile berbasis android dibagun dengan menggunakan Android Studio. Implementasi berdasarkan perancangan sebelumnya, Aplikasi ini terdiri tiga halaman yaitu halaman depan, halaman utama, dan halaman info.

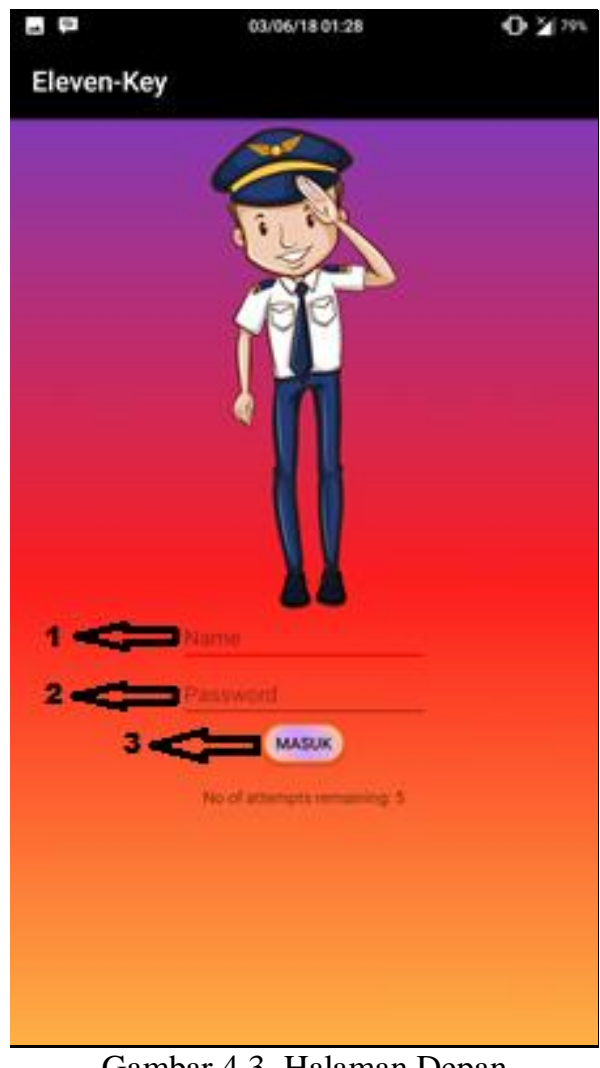

Keterangan :

1. Name, merupakan inputtext untuk menuliskankan nama. Nama yang diinputkan harus sesuai dengan yang disetting dalam program. 
2. Password, merupakan inputnumber untuk menuliskan password yang terdiri kombinasi angka, fungsinya untuk meningkatkan keamanan aplikasi.

3. Button Masuk, untuk lanjut ke halaman utama aplikasi (jika inputan nama dan password benar)

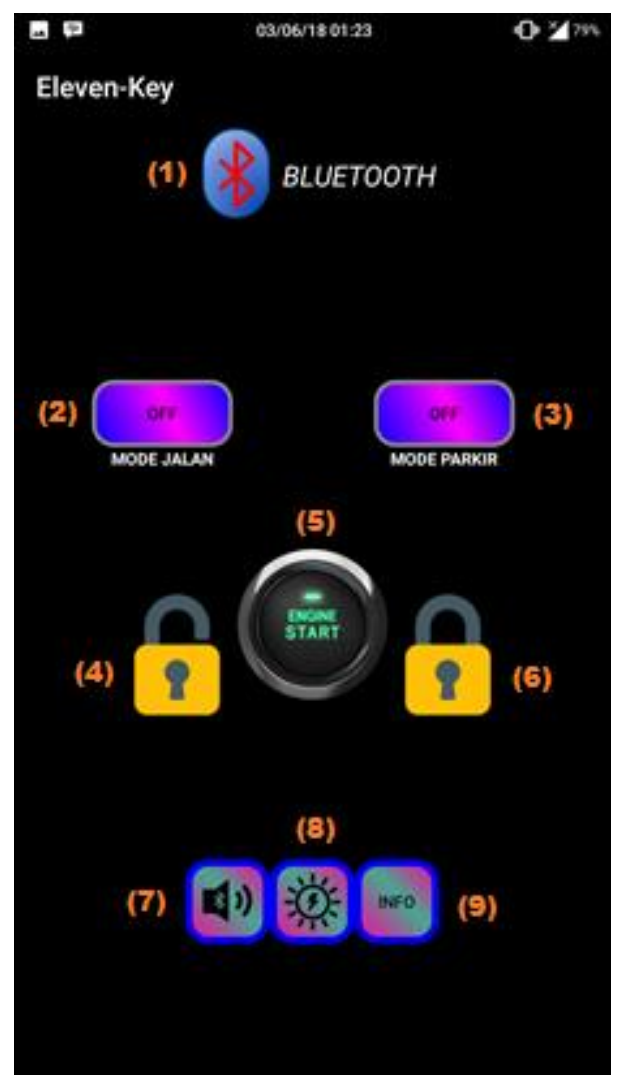

Gambar 4.4 Halaman Utama

Keterangan :

1. ImageButton Bluetooth, digunakan untuk mengaktifkan bluetoothAdapter smartphone dan melakukan pairing secara otomatis dengan modul bluetooth HC05 yang ada pada sistem.

2. ToggleButton Mode Jalan, digunakan untuk mengaktifkan Mode Jalan, dimana sensor akan nonaktif dan mesin sepeda motor akan nyala secara otomatis.

3. ToggleButton Mode Parkir, digunakan untuk mengaktifkan Mode Parkir dimana sensor getaran SW420 dan sensor Tegangan akan aktif.

4. ImageButton Kunci, digunakan untuk mengaktifkan kunci kontak sepeda motor.

5. ImageButton Start, digunakan untuk mengaktifkan dinamo starter sepeda motor selama $300 \mathrm{~ms}$.

6. ImageButton Stop, digunakan untuk memutus pengapian sepeda motor secara keseluruhan.

7. ImageButton ABS, digunakan untuk mengaktifkan lampu indikator serta buzzer. Berfungsi untuk memudahkan pemilik menemukan sepeda motornya.

8. ImageButton Auto, digunakan untuk menghidupkan mesin sepeda motor selama 5 menit selanjutnya akan otomatis mati. Fungsi untuk memudahkan peilik kendaraan dalam proses memanaskan kendaraan tanpa harus pergi atau kontak langsung dengan sepeda motor.

9. Button info, digunakan untuk pindah ke activity info.

\section{Implementasi Sistem}

Implementasi sistem keamanan pada sepeda motor ini menggunakan sensor Tegangan dan sensor getaran sebagai pendeteksi aksi pencurian, dimana logika yang digunakan untuk menetukan aksi pencuian dengan melihat output dari sensor getaran dan tegangan. Jika nilai yang dibaca dari sensor getaran sama dengan $\mathrm{HIGH}$ atau nilai yang dibaca oleh sensor tegangan besar sama dengan $9 \mathrm{~V}$, maka mikrokontroler akan mengaktifkan buzzer dan mengintruksikan modul GSM SIM800 untuk mengirim notifikasi berupa SMS kepada pemilik. Sedangkan sistem pengapian akan dihubungkan dengan relay 4channel agar dapat dikontrol secara keseluruhan, seperti kabel kunci kontak akan dihubungkan ke relay 1 .

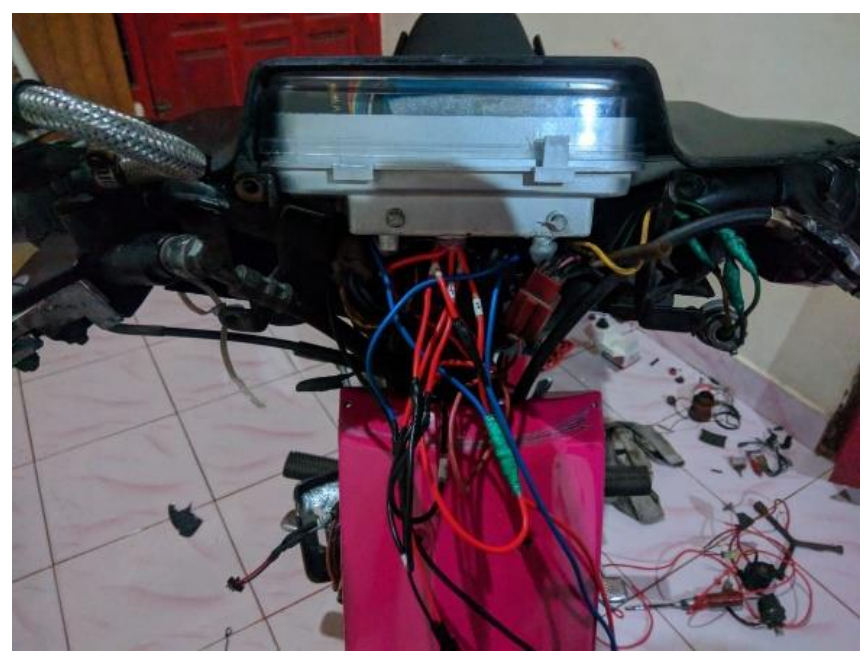

Gambar 4.5 Implementasi Sistem Tampak Depan

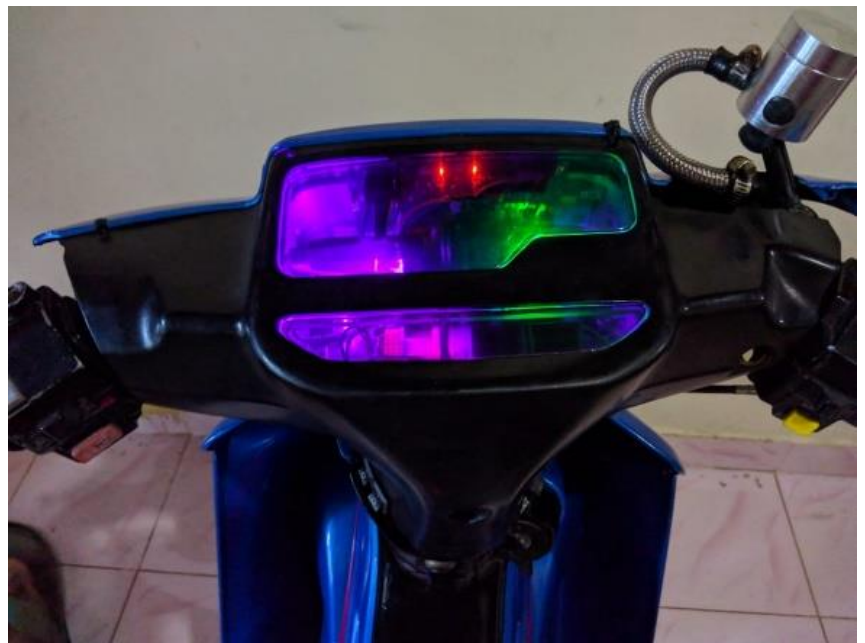

Gambar 4.6 Implementasi Sistem Tampak Atas

\section{Pengujian Mode PARKIR}

Pengujian mode Parkir merupakan pengujian yang dilakukan saat user memilih mode parkir yang ada pada aplikasi smartphone, berikut gambar tampilan aplikasi dan sistem pada sepeda motor. 


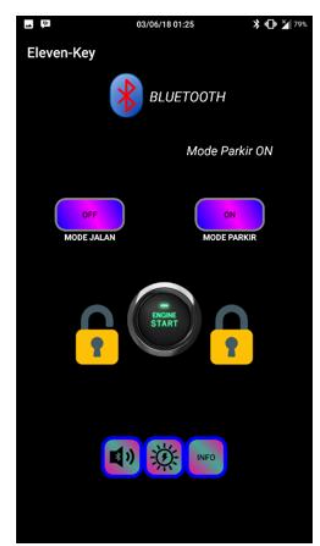

Gambar 4.7 Pengujian Mode Parkir

Pengujian secara keseluruhan bertujuan untuk menguji kemampuan sistem dari awal user membuka aplikasi, menginputkan nama dan password. Selanjutnya menghubungkan perangkat bluetooth pada smartphone dengan modul bluetooth $\mathrm{HC} 05$, dan menjalankan perintah sesuai kebutuhan user, yaitu memilih Mode Parkir. Pengujian kerja sistem saat user memilih mode parkir sistem akan secara otomatis mengaktifkan sensor getaran dan sesor tegangan untuk membaca dan mendeteksi prilaku-prilaku yang dapat membahayakan sepeda motor seperti membobol kunci kontak motor (dalam hal ini pengujian disimulasikan dengan mengaktifkan kunci kontak dengan kunci asli sepeda motor).Untuk sensor getaran prilaku ujinya adalah dengan memberi getaran kebody motor dengan tangan. Dalam sepuluh kali pengujian sembilan percobaan sistem mampu bekerja sesuai harapan dan satu kali gagal mengirimkan sms kepada pemilik

\section{E. Pengujian Mode JALAN}

Pengujian ini dilakukan untuk mengetahui apakah sistem mampu menjalankan skenario yang disetting dalam program saat user menekan tombol jalan pada aplikasi Eleven -Key. Skenario yang disetting sesuai dengan prilaku begal atau perampasan sepeda motor pada umumnya. Dimana saat user menggunakan sepeda motor maka kondisi pengapian dalam keadaan normal, namun dengan menggunakan mode jalan maka sistem akan tetap bekerja untuk menunggu intruksi dari aplikasi user,jadi user dapat mematikan mesin sepeda motor dengan menekan tombol stop pada aplikasi. Contoh kasusnya saat pemilik mengendaraai sepeda motor maka saat diperjalanan sepeda motor dirampas atau dibegal, maka pemilik dapat mematikan mesin sepeda motor secara keseluruhan (tidak dapat nyala dengan stater ataupun dengan kick stater/engkol).

Pada mode jalan ini user hanya perlu menekan tombol jalan dan pada aplikasi akan tertera bahwa mode jalan sedang aktif. Selanjutnya aplikasi Eleven-Key akan mengirimkan perintah kepada mikrokontroler untuk mengaktifkan kunci kontak sepeda motor dan mengidupkan mesin secara otomatis. Pemilik dapat mematikan mesin secara manual dengan menekan tombol STOP pada apliasi. Untuk mengetahui posisi sepeda motor user dapat menekan tombol ABS pada aplikasi maka sistem akan mengirimkan koordinat BTS kepada pemilik.
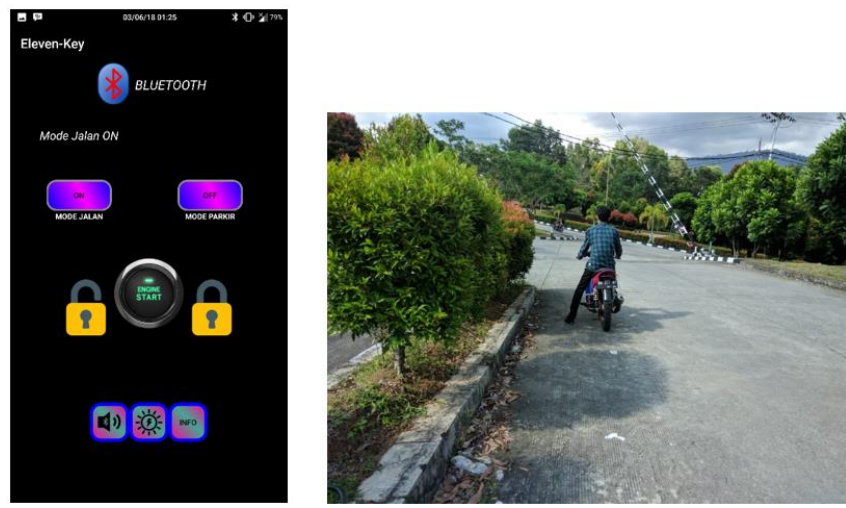

Gambar 4.8 Pengujian Mode Jalan

\section{PENUTUP}

\section{A. Kesimpulan}

Dari hasil pengujian dan analisa alat keamanan sepeda motor berbasis mikrokontroler dan modul GSM yang dilakukan, maka dapat diambil kesimpulan sebagai berikut:

1. Sistem dapat mendeteksi aksi pencurian sepeda motor diarea parkir menggunakan sensor getaran SW420 dengan presentase keberhasilan $100 \%$ dan menggunakan sensor tegangan yang dipasangkan pada kabel kunci kontak motor dengan presentase error sebesar $0.026 \%$.

2. Sistem dapat memberikan notifikasi kepada pemilik ketika terjadi usaha pencurian sepeda motor (bahaya) dengan modul GSM SIM800 untuk mengirimkan SMS kepada pemilik dengan rata-rata waktu pengiriman 7.212 detik. Sedangkan untuk komunikasi smartphone ke modul GSM berhasil dilakukan dengan waktu pengiriman SMS rata-rata yaitu. 4.869 detik.

3. Mikrokontroler dapat menerima perintah yang dikirimkan user dari smartphone melalui komunikasi bluetooth dengan jarak rata-rata 10 meter untuk dapat bekerja dengan baik.

4. Sistem dapat menghidupkan dan mematikan mesin sepeda motor yang sedang nyala dengan Relay 4 channel dengan nilai presentase keberhasilan $100 \%$.

\section{B. Saran}

Mengingat masih terdapat beberapa kekurangan dalam penelitian ini, maka perlu dilakukan perbaikan untuk lebih mengoptimalkan kinerja sistem ini :

1. Untuk penelitian selanjutnya dapat menggunakan modul kamera untuk mengambil gambar pelaku saat terjadi perampasan (begal).

2. Untuk penelitian selanjutnya agar dapat menambahkan fitur yang mampu menampilkan posisi sepeda motor secara realtime. 
3. Untuk penelitian selanjutnya dapat menambahkan jumlah sensor Getaran agar proses pendeteksian lebih baik.

\section{REFERENSI}

[1]Suryamin. 2018. Perkembangan jumlah kendaraan bermotor. http://www.bps.gp.id/. Diakses tanggal 10 April 2018, Pukul 13.22 WIB.

[2]Chania, ER. 2017. https://www.merdeka.com/peristiwa/sepanjang-2017terjadi-2709-kasus-curanmor-di-sumatera-barat. Diakses tanggal 07 Januari 2018, Pukul 23.11 WIB.

[3]Priliawito, Eko. 2013. Ini Cara Kerja "Cairan Setan" Untuk Pencurian

Motor.http://metro.news.viva.co.id/news/read/467402 inicara-kerja cairan setan untuk pencurian motor. Diakses tanggal 10 Januari 2018, Pukul 11.11 WIB.

[4]Suharjo, Beman, Staven Falentino dan S.Liawatimena. 2011. Perancangan Sistem Keamanan Sepeda Motor Dengan Sistem Sidik Jari. Jakarta :Jurnal Ilmiah Library Vol.19, No 1.

[5] Arif Utama, Frisman. 2017. Implementasi Near Field Comunication (NFC) pada kunci kendaraan roda dua berbasis android. Universitas Andalas. Program Studi Sistem Komputer.

[6]Arduino Uno. http://arduino.cc/. Diakses tanggal 7 Maret 2018, Pukul 21.11 WIB.

[7]Danu, Marantika. 2017. Rancang bangun sistem kunci kombinasi berbasis mikrokontroler pada kendaraan roda dua. Universitas Andalas. Program Studi Sistem Komputer.

[8]T. Igoe, 2011. Making Things Talk, 2nd ed. Sabastopol : O'reilly Media.

[9]Susnea I. dan M. Mitescu. 2005.Microcontrollers in Practice.Springer.New York.

[10]Achlison, Unang. 2015. Sistem keamanan kendaraan SUZUKI SMASH menggunakan ATmega 8 dengan sensor Bluetooth HC-06 berbasis android. Semarang.

[11]Modul GSM SIM 800 . http://www.belajarduino.com/2016/05/sim8001-gsmgprsmodule-to-arduino.html. Diakses tanggal 11 Maret 2018. Pukul 00.55 WIB.

[12]Syahrul, 2014. Pemrograman Mikrokontroler AVR Bahasa Assembly dan C. Informatika . Bandung.

[13]Iqbal. 2007. Cara Kerja Bluetooth. Ilmu Komputer.

[14]Tim DiyTech (2012). Bluetooth Module. http://diytech.net/2012/03/07/ dalam-beberapa-aplikasiatau-disain-kadangkala-kitamemerlukan/. Diakses tanggal 14 maret 2018, Pukul 21.52 WIB.
[15]Adriansyah, Andi. Tanpa tahun. Rancang bangun prototype elevator menggunakan mikrokontroler arduino ATmega 328P. Jakarta .universitas mercu.

[16]Prayogi, Gesit. 2017. Transformasi Fitur Keamanan Sepeda Motor. https://kumparan.com/@kumparanoto/transformasi-fiturkeamanan-sepeda motor . Diakses tanggal 14 Maret, Pukul 15.50 WIB.

[17]Tanpa Nama. 2014. Mengenal fungsi secure key shutter (SKS). https://www.hondacengkareng.com/mengenal-fungsisecure-key-shutter-sks-pada-motor-honda/. Diakses tanggal 15 Maret, pukul 12.38 WIB.

[18]Tanpa Nama. 2016. Kenalan dengan cara kerja kunci pintar Yamaha aerox 155R.http://www.tribunnews.com/otomotif/2016/11/05/ kenalan dengan cara kerja kunci pintar yamaha-aerox-155. Diakses tanggal 15 Maret. Pukul 12.50 WIB.

[19]Adi, Iman. 2015. Fitur autosafe anti maling Yamaha GT125 eagle eye http://www.review1 st.com/news/otomotif/yamaha-gt125eagle-eye-kini-berfitur-autosafe-anti-maling/. Diakses tanggal 15 Maret, pukul 12.57 WIB.

[20]Azmi, Nabila Ayu. 2014. Modus operandi kejahatan pencurian kendaraan bermotor roda dua. Universitas briwijaya. Malang .

[21]Fitriandi, Afrizal. 2016. Rancang bangun alat monitoring arus dan tegangan bebasis mikrokontroler dengan sms gateway. Universitas lampung. Bandar lampung.

[22]KBBI, http://kbbi.web.id/begal. Diakses tanggal 20 April 2018. Pukul 09.44 WIB

[23]Yoseph Pencawan (Editor). 2017. Apa Sih Motif \& Profil Pelaku Begal Motor? Begini Menurut Polis, sumatera bisnis. http://sumatra bisnis.com /read/20150319/8/55958/apa sih motif profil-pelakubegal-motor-begini-menurut-polisi. Diakses tanggal 20 April 2018. Pukul 09.58 WIB

[24]https://ruangmahasiswa.com/tips/tips-mencegah-danmenghindari kejahatan-begal/. Diakses tanggal 20 April 2018. Pukul 10.50 WIB

[25]https://lk2fhui.law.ui.ac.id/aksi-pembegalan-yangmeresahkan-masyarakat/. Diakses tanggal 20 April 2018. Pukul 10.51 WIB

[26]Yuniar, Supriadi. 2014. Semua Bisa Menjadi Programmer Android. Elex Media : Bandung

[27]Kurniawan, Dwi Ely.2016. perancangan sistem pengamanan sepeda motor menggunakan mikrokontroler raspberry Pi dan smartphone android. Politeknik caltex Riau. 